\title{
KONSTRUKSI SOSIAL PEMBERITAAN KASUS SIMULATOR SIM DI MEDIA ONLINE KOMPAS.COM
}

\author{
Slamet Dodi Kresno \\ (slametdodikresno62@gmail.com) \\ (Mahasiswa Ilmu Komunikasi Universitas Semarang)
}

\begin{abstract}
Thisis a descriptive study using a qualitative approach. The method used in this research is to use the model of Robert framing. N.Entman. This model is used to determine how the mass media to construct reality with four elements: define problems, diagnose causes, make moral judgments and treatment recommendation. The method used is qualitative research and analysis of framing. The research was conducted by collecting data from websites related cases sim simulator.

Results showed that online media news Kompas.com construct simulator sim case based on two issues will find that one of the suspectsis a police officer Inspector General Djoko Susilo abuse of power and authority toenrich them selves and others and relationships with the Police Commissionis getting better.
\end{abstract}

Kata Kunci : Komunikasi, Analisis Freming, Kontruksi Sosial

\section{PENDAHULUAN}

Korupsi merupakan fenomena sosial yang hingga kini masih belum dapat diberantas oleh manusia secara maksimal. Korupsi tumbuh seiring dengan berkembangnya peradaban manusia. Tidak hanya di Indonesia, korupsi juga tumbuh subur di belahan dunia yang lain, bahkan di Negara yang dikatakan paling maju sekalipun. Suatu negara tidak akan maju bila pada para pejabat ataupun staf melakukan korupsi, bahkan dapat dikatakan korupsi di Indonesia sudah tersistem baik secara langsung ataupun tidak langsung, oleh karena itu pemerintah mendirikan suatu Lembaga yaitu, Komisi Pemberantasan Korupsi yang saat ini di pimpin oleh Abraham Samad.

Korupsi berasal dari bahasa Latin coruptio dan corruptus yang berarti kerusakan atau kebobrokan. Dalam bahasa Yunani corruptio perbuatan yang tidak baik, buruk, curang, dapat disuap,tidak bermoral, menyimpang dari kesucian, melanggar norma-norma agama, materil, mental, dan umum. Korupsi merupakan tindakan melawan hukum untuk memperkaya diri sendiri/orang lain (perseorangan atau sebuah korporasi) , yang secara langsung maupun tidak langsung merugikan keuangan atau prekonomian negara, yang dari segi materiil perbuatan itu dipandang sebagai perbuatan yang bertentangan dengan nilai-nilai keadilan masyarakat. Korupsi berdasarkan pemahaman pasal 2 Undang-Undang Nomor 31 Tahun 1999 yang diubah menjadi Undang-Undang Nomor 20 Tahun 2001.

Saat ini lembaga tinggi Negara Polri tersebut sedang menjadi sorotan publik terkait pengadaan alat simulator surat izin mengemudi yang di perkirakan telah merugikan Negara hingga seratus miliar lebih. Kasus simulator SIM yang sedang ramai diberitakan oleh media massa bermula ketika Bambang $S$ Sukotjo, Direktur Utama PT Inovasi 
Teknologi Indonesia (PT ITI). Dia disangka melakukan penipuan dan penggelapan anggaran pengadaan simulator di Markas Korps Lantas Polri. Perkara pun melebar. Bambang mengungkap soal suap dalam proyek senilai Rp 198 ,7 miliar itu. Awalnya, PT ITI digandeng oleh perusahaan pemenang tender, yakni PT Citra Mandiri Metalindo Abadi (PT CMMA) untuk menyediakan simulator. Diduga terjadi mark up harga yang sangat besar untuk pengadaan simulator kendaraan roda dua maupun roda empat dari PT CMMA ketika dijual kepada Korlantas Polri. Pihak Bambang lalu meminta KPK mengusut dugaan mark up itu. Hasil penyelidikan, KPK menemukan cukup bukti adanya suap kepada Inspektur Jenderal Djoko Susilo selaku Direktur Lantas Polri ketika itu. Melalui perantara, Djoko diduga menerima suap senilai $\mathrm{Rp} 2$ miliar dalam proyek itu. (Lipsus.Kompas.com diunduh pukul 18.01wib tgl 19 Mei 2013)

Seperti yang diberitakan banyak media massa, KPK telah menetapkan Kepala Korlantas saat itu, Inspektur Jenderal Djoko Susilo, sebagai tersangka dalam penyidikan perkara tersebut. Namun, pihak Polri mengaku juga tengah melakukan penyelidikan perkara yang sama. Memang, hanya beberapa hari setelah KPK menyidik kasus korupsi simulator, tiba-tiba Polri juga menyidiknya. Padahal mengenai dugaan adanya korupsi dalam pengadaan simulator itu, Polri sebelumnya sempat menyatakan tak ditemukan ada korupsi sebagaimana pengusutan Inspektorat Pengawasan Umum. Terjadi kontra antar dua lembaga penegak hukum yaitu POLRI dan KPK terkait siapa yang paling berwenang mengusut kasus simulator tersebut. Sampai akhirnya Presiden berpidato dan menginstruksikan Polri menyerahkan sepenuhnya kasus simulator kepada KPK.

Berbagai media massa mulai dari media cetak maupun media on line ramai memberitakan kasus tersebut. Media massa online hadir sebagai bentuk diterimanya teknologi internet sebagai alat berkomunikasi dan menyebarkan informasi ke khalayak. Media online merupakan media massa generasi ketiga setelah media cetak, yang memiliki kelebihan kecepatan dalam memberikan informasi terkini, berbagai peristiwa aktual selalu di up date setiap saat serta bisa terbit kapan saja selama berada dalam jaringan internet. Apalagi seiring dengan majunya teknologi gadget dengan hadirnya smartphone lengkap dengan koneksi internet.

Media massa memiliki peran strategis sebagai saluran yang menyampaikan informasi kepada publik secara serempak diantara khalayak yang sedang menggunakan media tersebut.

Tiap - tiap media massa dalam beritanya melakukan pembingkaian terhadap suatu peristiwa yang terjadi. Pembingkaian ini dipengaruhi dari berbagai macam faktor ideologi dan faktor lainnya yang terdapat dalam media maupun jurnalis. Hal inilah yang dapat membedakan pembingkaian dari satu media dengan media lainnya, sehingga suatu peristiwa yang sama dapat dimaknai secara beragam. Media merupakan subjek yang mengkonstruksi realitas mana yang ditonjolkan dan ditutupi, pembingkaian tersebut tentu saja melalui proses konstruksi.

Menurut Eriyanto (2005:24), ada beberapa tingkatan peran media dalam membentuk realitas :

a) Media membingkai peristiwa dalam bingkai tertentu. Peristiwa-peristiwa yang kompleks disederhanakan sehingga membentuk pengertian dan gagasan tertentu. Sebuah peristiwa didefinisikan dengan narasumber, 
pemilihan kata, urutan peristiwa sehingga menunjukkan pada pembaca bagaimana media tersebut sepakat atau tidak dengan peristiwa yang terjadi.

b) Media memberikan simbol-simbol tertentu pada peristiwa dan aktor yang terlibat dalam berita. Pemberian simbol tersebut akan menentukan bagaimana peristiwa dipahami, siapa yang dilihat sebagai pahlawan dan musuh. Media pun menyeleksi ucapan tertentu dari sumber berita, sehingga khalayak pun menerima citra tertentu akan sebuah peristiwa dan aktornya.

c) Media menentukan apakah peristiwa ditempatkan sebagai hal yang penting ataukah tidak. Panjang pendek berita, pemilihan halaman untuk menempatkan sebuah berita pun dilakukan oleh media.

Penelitian dengan menggunakan analisis framing dengan model Robert N. Entman sendiri, kebanyakan digunakan untuk mengetahui atau membandingkan satu media massa dengan media massa lainnya, seperti penelitian yang dilakukan Hendriyansah Amanu (2013) "krisis kepengurusan PPSI di okezone.com dan viva.co.id", hasilnya adalah okezone.com dan viva.co.id memiliki cara yang berbeda dalam membingkai pemberitaannya. Analisis framing menurut Eriyanto(2002:3), mengemukakan jika analisis framing dapat digambarkan sebagai analisis untuk mengetahui bagaimana realitas (peristiwa, aktor, kelompok, atau apa saja) dibingkai oleh media.

Dari beberapa media on line seperti republika on line, Detik.com, metronews.com, Kompas.com merupakan beberapa media massa on line yang memberitakan kasus simulator sim tersebut. Dari beberapa media on line yang memberitakan kasus tersebut, peneliti memilih Kompas.com sebagai objek penelitian karena salah satu portal terpopuler di Indonesi,a kompas termasuk media yang sangat kritis terhadap kondisi sosial maupun politik di Indonesia dengan kritiknya yang tajam. Karena sejak awal berdirinya sebagai media yang mengidentifikasikan pembawa kepentingan dan suara hati rakyat, Kompas merasa mampu menyampaikan berita yang aktual dan kontroversi Ideologi.

Kompas.com berdiri pada tahun 1997 dengan nama Kompas On line. Saat itu, Kompas On line hanya berperan sebagai edisi internet dari Harian Kompas. Kemudian pada tahun 1998 Kompas On line merubah namanya menjadi Kompas.com dengan berfokus pada pengembangan isi, desain, dan strategi pemasaran yang baru. Kompas.com pun memulai langkahnya sebagai portal berita terpercaya di Indonesia. Dengan perubahan penampilan yang signifikan. Mengusung ide "Reborn", Kompas.com membawa logo, tata letak, hingga konsep baru di dalamnya. Lebih kaya, lebih segar, lebih elegan dan tentunya tetap mengedepankan unsur userfriendly dan advertiser-friendly.

Sinergi ini menjadikan Kompas.com sebagai sumber informasi lengkap, yang tidak hanya menghadirkan berita dalam bentuk teks, namun juga gambar, video, live streaming. Perubahan ini pun mendorong bertambahnya pengunjung aktif Kompas.com di awal tahun 2008 yang mencapai 20 juta pembaca aktif per bulan, dan total 40 juta page views/impression per bulan. Saat ini, Kompas.com telah mencapai 120 juta page view perbulan.

Kompas merupakan satu-satunya media nasional Indonesia yang mempunyai editorial yang bersifat internasional sering dijadikan media luar negeri sebagai referensi mereka. Kompas juga terkenal dengan idealisme dan semangat untuk memberikan 
informasi yang objektif, netral kepada masyarakat. Karena itulah Penulis tertarik meneliti bagaimana Kompas.com dalam membentuk konstruksi sosial terkait pemberitaan kasus simulator SIM yang telah menetapkan petinggi Polri Inspektur Jenderal Djoko Susilo sebagai tersangka?

\section{TINJAUAN PUSTAKA}

\section{Berita}

Berita adalah hasil rekonstruksi dari realitas sosial yang terdapat dalam kehidupan, berita adalah apa yang ditulis surat kabar cetak maupun on line, apa yang disiarkan radio, dan apa yang ditayangkan televisi. Berita didefinisikan sebagai informasi baru, penting, dan bermakna, berpengaruh kepada khalayaknya serta layak dinikmati.

Dalam kamus komunikasi, berita adalah laporan mengenai hal atau peristiwa yang baru terjadi, menyangkut kepentingan umum dan disiarkan secara cepat oleh media massa : surat kabar, majalah, siaran radio dan siaran televisi. Berita, menurut Doug Newson dan James A. Wollert dalam Media Writing : News For the Mass Media (1985 : 11) mengemukakan dalam definisi sederhana berita adalah apa saja yang ingin dan perlu diketahui orang atau lebih luas lagi oleh masyarakat (dalam Sumadiria, 2005:64). Dikutip juga pendapat Nancy Nasution, berita yakni: Laporan tentang peristiwa-peristiwa yang terjadi, yang ingin diketahui oleh umum, dengan sifat-sifat aktual, terjadi di lingkungan pembaca, mengenai tokoh terkemuka, akibat peristiwa tersebut berpengaruh terhadap pembaca (dalam Basuki 1983:1).

Dari beberapa definisi berita menurut para ahli diatas, walaupun berbeda - beda namun terdapat persamaan yang mengikat pada berita, meliputi : menarik perhatian, luar biasa, dan terkini. Karena itu, bisa disimpulkan bahwa berita adalah laporan tercepat mengenai fakta atau ide terbaru yang benar, menarik dan atau penting bagi sebagian besar khalayak, melalui media berkala seperti surat kabar, radio, televisi, atau media online internet. (Sumadiria, 2005:65).

\section{New Media (Media Baru)}

Pada dasarnya, media massa memiliki fungsi penghantar dalam menyebar berbagai macam pengetahuan, menyelenggarakan kegiatan dalam lingkungan publik yang dapat dijangkau segenap anggota masyarakat secara bebas, sukarela, umum dan murah, hubungan antara pengirim dan penerima seimbang dan sama serta mampu menjangkau lebih banyak orang daripada institusi lainnya (McQuail, 1987: 51).

Media massa yang baik seharusnya menjalankan fungsi yang sama dengan komunikasi massa seperti yang dikemukakan oleh Harold Laswell, diantaranya untuk menginformasikan (to inform), untuk mendidik (to educate), dan untuk menghibur (to entertain). Menurut undang -undang no.40 tahun 1999 tentang pers, bahwa fungsi pers adalah untuk menginformasikan, mendidik, menghibur, dan melakukan pengawasan sosial (social control) baik pada perilaku publik maupun pada penguasa (Undang - undang No. 40 Tahun 1999 Tentang Pers).

Media online sebenarnya tidak jauh beda dengan media massa konvensional hanya saja media online didapatkan melalui internet. Secara karakteristik media online bisa menjangkau pelanggan lebih dekat, kepuasan kepada pembaca karena mudah diakses, serta berita aktual yang dapat di perbaharui 
secara real time. Sedangkan media konvensional harus melalui proses kaidah - kaidah bahasa dan penulisan.

\section{Teori Framing}

Teori framing sebenarnya banyak mendapat pengaruh dari ranah psikologi dan sosiologi. Pendekatan psikologi melihat bagaimana pengaruh kognisi seseorang dalam membentuk skema tentang diri, sesuatu, atau gagasan tertentu. Framing banyak berhubungan dengan kognitif : bagaimana seseorang memahami dan melihat realitas dengan skema tertentu. Sementara dari sosiologi konsep framing dipengaruhi oleh pemikiran Erving Goffman. Menurut Goffman, yang pada dasarnya manusia secara aktif mengklasifikasikan dan mengkategorisasikan pengalaman hidup ini agar mempunyai arti atau makna. Setiap tindakan manusia pada dasarnya mempunyai arti, dan manusia berusaha memberi penafsiran atas perilaku tersebut agar bermakna dan berarti. (Eriyanto, 2002: 71).

Analisis ini mencermati strategi seleksi, penonjolan dan keterikatan fakta kedalam berita agar lebih bermakna, lebih menarik, lebih berarti, atau lebih diingat untuk menggiring interpretasi khalayak sesuai dengan perspektifnya (Sobur, 2002: 162).

Dalam perspektif komunikasi, framing mewakili tradisi yang mengedepankan pendekatan atau perspektif multidisipliner untuk menganalisis fenomena atau aktivitas komunikasi. Di dalam (Eriyanto, 2002 : 69) terdapat dua aspek dalam framing. Pertama, memilih fakta/realitas. Proses memilih fakta ini didasarkan pada asumsi, wartawan tidak mungkin melihat peristiwa tanpa perspektif. Dalam memilih fakta ini selalu terkandung dua kemungkinan: apa yang dipilih (included) dan apa yang dibuang (exluded). Pembuatan frame itu sendiri didasarkan atas berbagai kepentingan internal maupun eksternal media, baik teknis, ekonomis, politis ataupun ideologis. Sehingga pembuatan sebuah wacana tidak saja mengindikasikan adanya kepentingan - kepentingan itu, tetapi juga bisa mengarahkan hendak dibawa kemana isu yang diangkat dalam wacana tersebut (Hamad, 2005: 18).

Robert N. Entman melihat framing dalam dua dimensi besar : seleksi isu dan penekanan atau penonjolan aspek aspek tertentu dari realitas/isu (Eriyanto : 2002: 186). Kemudian untuk mendefinisikan realitas yang akan diteliti, Entman mengajukan empat tahap yaitu : define problems, diagnose couses, make moral judgment, treatment recommendation (Eriyanto, 2002 : 188). Define problems (Pendefinisian masalah) merupakan bingkai utama yang menekankan bagaimana sebuah peristiwa dipahami oleh wartawan. Dianose couses (Memperkirakan penyebab masalah), merupakan elemen framing untuk membingkai siapa yang dianggap aktor dari sebuah peristiwa. Make moral judgment (membuat pilihan moral) adalah elemen framing yang dipakai untuk memberi argumentasi pada pendefinisian masalah yang sudah dibuat. Treatment recommendation (menekankan penyelesaian) merupakan elemen yang dipakai untuk merekomendasikan jalan penyelesaian yang dipilih untuk menyelesaikan masalah (Eriyanto, 2002: 189-191)

\section{Konstruksi Sosial Media Massa}

Teori yang membahas hubungan antara media dengan realitas sosial adalah teori konstruksi sosial. Individu mengkonstruksi realitas sosial dan mengkonstruksinya dalam dunia realitas, memantapkan realitas itu berdasarkan subyektifitas individu lain 
dalam institusi sosialnya (Sobur, 2002 : 90). Realitas sosial tersebut akan memiliki makna ketika di konstruksi oleh manusia secara subyektif yang kemudian diyakini secara objektif oleh masyarakat.

Peter L. Berger dan Thomas Luckmann pada tahun 1966 melalui bukunya "The Social Construction of Reality : A Treatise In The Sociological of Knowledge" menjelaskan bahwa individu secara intens menciptakan suatu realitas yang dimiliki dan dialami bersama secara subyektif. Berger dan Luckmann memulai penjelasan realitas sosial dengan memisahkan pemahaman antara "kenyataan" dan "pengetahuan" (Sobur, 2002 : 91). Mereka mengartikan realitas sebagai kaualitas yang terdapat di dalam realitas - realitas yang diakui memiliki keberadaan yang tidak bergantung kepada kehendak kita sendiri. Sementara pengetahuan didefinisikan sebagai kepastian bahwa realitas - realitas itu nyata dan memiliki karakteristik secara spesifik (Sobur, 2002 : 91).

Realitas sosial menurut pandangan konstruktivis, setidaknya sebagian merupakan produksi manusia, hasil proses budaya, termasuk penggunaan bahasa (Eriyanto, 2002: xi). Konsep mengenai konstruksionisme diperkenalkan oleh sosiolog interpretatif, Peter L. Berger bersama Thomas Luckmann yang banyak menulis karya dan menghasilkan tesis mengenai konstruksi sosial atas realitas (Eriyanto, 2002 : 13).

\section{METODOLOGI PENELITIAN}

\section{Bentuk dan Strategi Penelitian}

Peneliti akan menggunakan bentuk riset deskriptif kualitatif dan menggunakan metode analisis framing dengan model Robert N. Entman.
Paradigma ini beranggapan bahwa pembuat teks berita sebagai penentu yang akan mengarahkan pola pikir khalayak. Seperti pertanyaan utama dari paradigma konstruksionis adalah bagaimana peristiwa atau realitas dikonstruksi, dan dengan cara apa konstruksi itu di bentuk (Eriyanto, 2002 :37 - 38)

Penelitian ini akan menggunakan metode analisis framing dengan pendekatan konstruksionis. Paradigma konstruksionis memandang bahwa tidak ada realitas yang obyektif, karena realitas tercipta melalui proses konstruksi dan pandangan tertentu.

\section{Data dan Sumber data}

primer peneliti bersumber dari lipsus.kompas.com, terutama berita terkait "Kasus Simulator SIM". Data primer merupakan sumber data penelitian yang diperoleh secara langsung dari sumber asli (Sangadji. A.M \& Sopiah, 2010:171).Data sekunder merupakan data yang diperoleh dari catatan-catatan dokumen dan juga sumber dari kepustakaan (Sangadji. A.M \& Sopiah, 2010:172). Peneliti memilih referensi beberapa buku dan beberapa website sebagai rujukan dan penguat data.

\section{Teknik Sampling}

Pada penelitian kualitatif ini, sampel yang digunakan adalah purposive sampling, yaitu tenik pengambilan sampel sumber data dengan pertimbangan tertentu (Sugiyono, 2008:60). Sampel diambil disesuaikan dengan tujuan peneliti yaitu dengan memilih berita yang terkait dengan kasus simulator sim.

\section{Teknik Pengumpulan Data}

Adapun teknik yang digunakan dalam mengumpulkan data adalah melalui studi pustaka dan observasi di 
media on line yang terkait dengan pemberitaan kasus simulator sim.

\section{Validitas Data}

Peneliti akan menggunakan analisis triangulasi sebagai penguat data. "Triangulasi adalah aplikasi studi yang menggunakan multimetode untuk menelaah fenomena yang sama" Denzin (dalam Moleong, 2004), membedakan empat macam triangulasi diantaranya dengan memanfaatkan penggunaan sumber, metode, penyidik dan teori.

\section{Teknik Analisis Data}

penelitian ini, menggunakan model analisis framing Robert N. Entman untuk menganalisis data, dengan menggunakan empat tahapan yaitu : karena menurut pengamatan peneliti terhadap pemberitaan yang dilakukan Kompas.com mengidentisifikasi masalah, memperkirakan sumber masalah, membuat penilaian moral, memberikan penyelesaian masalah tersebut.

\section{HASIL DAN PEMBAHASAN}

Berdasarkan hasil analisis, penulis melihat ada dua aspek realitas yang sangat ditonjolkan selain aspek lainnya oleh kompas.com dalam pemberitaan kasus simulator surat izin mengemudi (SIM) yaitu permasalahan penegakan hukum dan sosial politik.

Menurut Entman (dalam Eriyanto, 2000:94) melihat framing dalam dua dimensi besar, yaitu seleksi isu dan penekanan atau penonjolan aspek-aspek tertentu dari realitas atau isu. Penonjolan adalah proses pembuat informasi menjadi lebih bermakna, lebih menarik, berarti atau lebih diingat oleh khalayak.

Kompas.com dalam melakukan framing berita cenderung mengindikasi sikap dari perusahaan pers bersangkutan. Hal ini dapat dilihat dari proses pemilihan Judul, lead, visual image, serta penempatan sebagai headline maupun paging. Karena dalam dunia jurnalistik, berita dan framing adalah dua hal yang tidak dapat dipisahkan bahkan satu sama lain tidak bisa berdiri sendiri.

Media selain sebagai suatu alat untuk menyampaikan berita, penilaian atau gambaran umum tentang banyak hal, ia mempunyai kemampuan utnuk berperan sebagai institusi yang dapat membentuk opini publik. Media massa memaknai sebuah peristiwa secara berbeda-beda dan media juga melakukan penonjolanpenonjolan aspek tertentu dalam berita yang disajikannya.

\section{KESIMPULAN}

Berdasarkan hasil penelitian dan pembahasan tentang pembingkaian berita yang dilakukan terhadap Kompas.com dalam pemberitaan kasus simulator SIM, maka dapat ditarik kesimpulan sebagai berikut :

1. Kontruksi sosial kasus Simulator SIM dalam Kompas.com dilihat berdasarkan dua isu yang ditonjolkan Kompas.com yaitu tersangka Inspektur Jendral Djoko Susilo dan hubungan POLRI dengan KPK

2. Kompas.com dalam pemberitaannya cenderung melihat KPK semakin berani mengusut tuntas kasus korupsi di negeri ini. Kecenderungan ini terlihat dari seringnya Kompas.com menampilkan pemberitaan tentang keberhasilan atas kinerja KPK dalam mengusut Korupsi.

\section{DAFTAR PUSTAKA}

Ardianto, E, \& Erdinaya, L. 2004. Komunikasi massa suatu 
pengantar. Bandung : Simbiosa Rekatama Media

Bungin, Burhan. 2008. Konstruksi Sosial Media Massa. Jakarta: Penerbit Prenada Kencana Group

Eriyanto. 2002. Analisis Framing : Konstruksi, Ideologi, dan Politik Media. Yogyakarta : LkiS

Eriyanto. 2000. Analisis Framing : Konstruksi, Ideologi, dan Politik Media. Yogyakarta : LkiS

Lexy J. Moleong. 2012. Metodologi Penelitian Kualitatif. Bandung : Remaja Rosda Karya
Littlejhon \& Karen.A Foss. 2009. Teori Komunikasi. Jakarta : Salemba Humanika

McQuail. 2011. Teori Komunikasi Massa. Jakarta : Salemba Humanika

Sangadji. E.M \& Sopiah. 2010. Metodologi Penelitian. Yogyakarta: Andi Offset

Sugiyono. 2008. Metode Penelitian Kuantitatif Kualitatif Dan $R \& D$. Bandung : Alfabeta

Sobur, Alex. 2004. Analisis Teks Media. Bandung : Remaja Rosda Karya 